\title{
Social Cultural Interaction in Harmony Between Religious People in Central Sulawesi
}

\author{
Sidik \\ Institut Agama Islam Negeri Palu \\ Jl. Diponegoro No.23, Lere, Kec. Palu Bar., Kota Palu, Sulawesi Tengah \\ 94221 \\ E-mail: sidikibrahim2@gmail.com
}

\begin{abstract}
Social and cultural interactions in social activities, cooperation, consensus decision-making, caring for others, and the environment can maintain religious harmony in the people of South Lore and West Lore Districts, Poso Regency. The social and cultural interactions can form a collective consciousness of the community to understand, respect, and appreciate religious diversity. Not surprisingly, if the social and cultural interactions are firmly in three activities in the community: traditional activities where social interaction occurs because the community respects local customs; humanity where through respect for humanity between communities, this social and cultural interaction occurs; and religion that regulates religious relations between communities that respect each other and respect the activities that the community carries out. From these three activities, the social and cultural interaction between community members in South Lore and West Lore Districts, Poso Regency can eliminate the potential for religious conflict and maintain harmony and harmony among various religious believers ot adherents.
\end{abstract}

Keywords: Social and cultural interaction, religious harmony, collective consciousness.

\section{A. Introduction}

Based on its origin, there are two types of religion, religions that come from God (heavenly religions or samawi religions) and religions that come from thought (Earth religions, ardiy religion, or cultural religion) (Nata 2014). For 
humans, religion is a nature that comes from three potentials, an instinct to defend oneself (garizah al-baqa), an instinct to purify something (Garizah altadayun), and an instinct to preserve offspring. Garizah al-tadayun is an instinct that Allah created for humans to purify and cult something. In this case, the diversity is human nature that human have since birth (Hafidz 2010).

Religion is human nature. Therefore, religion, as teaching and guidance, is inseparable from human life. Religion is the most fundamental necessity by humans (Hafidz 2010). Diversity in religion has been inherent in every human being since birth. Diversity is a wealth that must be accepted as a provision of God. Therefore, efforts to reject diversity in life will certainly not be possible (Galib 2014). Religion is sunnatullah. It is QS. Al-Hujurat: 13.

O mankind, indeed we have created you from male and female and made you peoples and tribes that you may know one another. Indeed, the most noble of you in the sight of Allah is the most righteous 1 of you. Indeed, Allah is Knowing and Aware.

Wahai, manusia, sungguh Kami telah menciptakan kamu dari seorang lakilaki dan seorang perempuan, kemudian Kami jadikan kamu berbangsabangsa dan bersuku-suku, tujuannya agar kamu saling mengenal. Sungguh, yang paling mulia di antara kamu di sisi Allah ialah orang yang paling bertakwa. Sungguh, Allah Maha Mengetahui (RI 2015).

Based on the verse, God shows his power by creating various human beings. It also explains that the most basic of diversity is that every human being always knows each other. On the other hand, God explains that it is easy to create humans without diversity, but God did not want it because He wants to see anyone who wants to do good by doing what He commands. Humans follow monotheism, but they still have conflicted with each other (Shihab 2002).

For the conflict to be resolved, God sent the Prophet to the people who conflicted. Humans who adhere to values following Islam will follow what has been taught by the Prophet. However, people who have weak faith will still not follow what the Prophet taught them. Diversity leads to two potentials, the potential for grace and the potential for curse or disaster. Both depend on how every human being can run and manage their diversity in life, including religious diversity.

The well-received diversity can be a blessing because it can create curiosity, appreciation, mutual understanding, co-existence, and collaboration in 
life. The exclusive attitude that arises in a pluralistic society will make diversity a problem. In addition, the attitude that appears in a pluralistic society is a reason why religious diversity can be a problem. It tends to lead religious people to religious conflict (Galib 2014). For people who have an exclusive attitude, diversities in beliefs, ethnicities, or cultures are not beauty, but something that threatens.

As a result, inter-religious conflicts often occur. The inter-religious conflicts because of religious exclusivity contribute to splits in society, such as the events that occurred in Situbondo, Tasikmalaya, Kupang, Sambas, Ambon, and Poso. The conflicts occurred because the religious diversities between adherents were not addressed properly.

However, sometimes the causes of inter-religious conflicts in a plural society are not purely religious factors. However, there are other aspects, such as economic, political, socio-cultural, or others. These cases include, among other things, the establishment of houses of worship, the ways of conveying religious teachings that are not following applicable regulations, or misunderstandings among religious adherents.

Therefore, education about the acceptance and appreciation of diversity is increasingly important. All religions teach goodness and peace. Islam, for example, always teaches compassion for all nature, Christianity teaches love, Buddhism teaches simplicity, Hinduism teaches Dharma, and Confucianism teaches wisdom. Hindu teachings in the Vedas are full of moral and ethical teachings to form a peaceful, friendly, and polite human person (Yunus 2012).

In the history of Muslims, the attitude of living in harmony has existed, and the Prophet Muhammad practiced it. At the beginning of building Medina, when the Prophet Muhammad saw migrated to Medina, the Prophet immediately realized the plurality of society in the city. The plurality that the Prophet encountered was not only ethnic diversities but also religious diversities. Seeing this religious plurality, the Prophet initiates to build togetherness with people from other religions. The initiative later resulted in the Medina Charter (Galib 2014). The charter contains several points of agreement related to religious harmony.

Inter-religious harmony is formed when there is intensive socio-cultural interaction between religious believers in society. This socio-cultural interaction is natural, and it is a fundamental need for the life of every religious 
community. Socio-cultural interaction is an integral part of the life for a pluralistic society. Then, this socio-cultural interaction results in harmony and tolerance in the Lembah Bada, especially in South Lore and West Lore Districts, Poso Regency. Although there have been conflicts between religious society, the people in South Lore and West Lore Districts have succeeded in maintaining peace because of social interactions strengthened by local culture.

Interestingly, the people in South Lore and West Lore Districts who are plural in terms of ethnicity, language, and religion can live side by side, in harmony, peace, mutual respect, and respect for one another. This culture of cooperation and togetherness also occurs in people with different religions. Based on Radar Online's data, South Lore and West Lore Districts have customary institutions that have a role in countering provocation efforts and successfully maintaining peace (SULTENG 2017).

The explanation above confirms that the cause of inter-religious harmony in South Lore and West Lore Districts is the intensive social and cultural interaction between various religious adherents. The interactions can strengthen the consciousness of society tolerance in the religion. Therefore, when conflicts between religious adherents occur in Poso, South Lore and West Lore Districts are relatively peaceful, and Peaceful inter-religious relations continue until today. All of this happened because of good social and cultural interactions that can build harmonious communities relations. Therefore, this study will discuss inter-religious harmony in South Lore and West Lore Districts, Poso Regency, Central Sulawesi due to social and cultural interactions in the society.

\section{B. Method}

This research is field research with a qualitative approach (Moleong 2016) which is presented descriptively in exposing the facts or phenomena of inter-religious harmony. The researcher uses a qualitative approach to examine a phenomenon of religious harmony in a society. The used data collection techniques are observation, interviews, and documentation. The researcher uses the data collection technique to obtain information about social and cultural interactions in religious harmony in South Lore and West Lore Districts, Poso Regency, Central Sulawesi.

Observations in this study are direct observation methods, namely collecting data by observing directly the object of this research, such as the 
geographical location of the South Lore and West Lore Districts and the activities carried out to foster inter-religious harmony (Surakhmad 1985). The interview is a method the researcher uses by conducting interviews with informants (Moleong 2016). The researcher directly interviews informants and resource persons such as the Camat, Village Heads, Religious Leaders, Traditional Leaders, Women's Leaders, and community and its leaders in South Lore and West Lore Districts, Poso Regency. Documentation is data collection by reviewing documents that support the completeness of the data. In this data collection technique, the researcher collects relevant data from several official documents or archives. In this documentation technique, the researcher uses a tape recorder for interview transcripts and a camera as evidence that the researcher researched the intended location.

There are three stages in data analysis. The first is to reduce the data into a complete narrative (Huberman 1992). The researcher reduces data from observations, interviews, and documentation into words that the researcher considers insignificant for this study, such as the state of the location and documentation that is not related to the research, jokes, and small talk from informants. The second is the presentation of the data. The researcher presents dat a that has been reduced in certain models to avoid misinterpretation of the data (Huberman 1992). This research is descriptive qualitative research. Therefore, the researcher presents the data in the form of words/sentences as a complete narrative. The third is data verification. In verifying the data, the researcher concludes by referring to the results of data reduction. The researcher chooses data following the research from the interviews, observations, and documentation.

\section{Result and Discussion}

Poso Regency stretches from southeast to southwest and from west to east. Most of its territory is the mainland of Sulawesi. Poso Regency, in general, is a forest and mountainous area. Another territory is the coast, partly located in the waters of Tomini Bay and Tolo Bay. After being separated from Tojo Ununa Regency, Its territory is about $8,712.25 \mathrm{~km}^{2}$ or $12.81 \%$ from the land area of Central Sulawesi. The people in the South Lore and West Lore Districts are Tobada. Tobada is one of the tribes in Poso Regency with a pluralistic society in very close social and familial relationships that make the people there always get along even though they have different beliefs (Radar 
Sulteng Online, 2019). From here, inter-religious harmony in the South Lore and West Lore Districts, Poso Regency, Central Sulawesi has survived well. In various activities, the society is united even though its religion and beliefs are different.

This harmonious religious life in the South Lore and West Lore Districts exists because the people are directly involved in cultural interaction and collaboration activities as a joint activity framed in the local culture. Culture is a means to build collective consciousness that binds individuals in a different society (Durkheim, 1998). Therefore, the researcher identifies these social and cultural interactions as follows.

\section{Social interactions}

Social interaction is a social activity such as intensive communication between religious adherents as a community (Irawan 2018). Social interaction is the key to harmony in social life and inter-religious relations (Jamaludin 2016). Through this social interaction, individuals are involved in communication and joint activities based on mutual respect. Without social interaction, there can be no harmonious life together. It happens because individual interactions will produce positive relationships in a social group. Such positive relationships will occur when people work together and talk to each other to achieve a common goal (Soekanto 2014). Therefore, social interaction is the basis of a social process that can build society harmony, especially interreligious harmony.

One of the efforts to strengthen brotherhood and tolerance among religious adherents is good communication and interaction between them. It happens to the people in the South Lore and West Lore Districts. They actively interact well in their daily life. This good social interaction creates harmony between religious communities in a conducive manner, and the potential conflict between religious adherents in society does not occur. Even if there are potential conflicts, they can avoid them through this social interaction because the intensive social interaction makes the people in the South Lore and West Lore Districts more respectful of religious harmony.

The people in the South Lore and West Lore Districts live in good bonds and interactions. This interaction puts forward the social values of religious adherents so that the potential for conflicts such as those that occurred a few years earlier can gradually decline. Tolerant attitudes, for example, appear 
when people celebrate religious holidays. On this holiday, religious adherents will congratulate each other. Muslims always congratulate Christians and vice versa. It is one way to maintain respectful interactions (Interview with Gawi Wengkau, Traditional Leader of the Tampo Bada Region, South Lore and West Lore Districts).

Religious adherents maintain harmony through social interaction implemented in their good communication (Irawan, 2018). Good communication between various religious adherents must be a priority for Christians, Protestants, Catholics, Hindus, and Muslims. The religious adherents must communicate with mutual respect and appreciation so that there is no harassing attitude between them. Due to good communication, the potential separation between religious adherents declines. The religious adherents do not want religious conflicts to occur again. The past religious conflicts have become significant lessons for the society to create interaction and communication to build a harmonious society.

One form of communication and interaction is to give each other good suggestions when there are problems. Social interaction creates a space for discussion about daily life or discussions about work (Wahyuni 2015). Muslim communities in the South Lore and West Lore Districts still have blood and kinship relations because many Muslim immigrants marry Bada natives. It strengthens the ties of brotherhood among the people (Results of Interview with Simanang Cikka).

People interact well with each other when they meet at a wedding or during a religious event. They interact with each other politely and do not bring up the issue of faith. When the riots in Poso occurred, people in the Bada remained safe and peaceful. There were a small number of Muslim communities who had fled to other areas. However, the majority community remained in Kulawi Selatan and Palu. After Poso City was safe, many people returned to Tampo Bada because it was a region where their ancestors were born and grew up. People fled to save themselves because they were traumatized by what had happened in some areas of Poso. However, the elders still urge the people not to leave Bada because the elders guarantee their safety. The people in Tampo Bada maintain harmony and peace because of blood relations and traditional and cultural values that still bind the community (Interview with Community Leader Hendrik Mangela). 
It shows that the society is very enthusiastic about maintaining interreligious harmony. The harmony among various religious adherents depends on cultural values (Geertz 2000). These cult ural values build social interaction among religious people in a harmonious and tolerant atmosphere. When viewed from how religious believers communicate, this social interaction exists because of collective consciousness (Durkheim 2017). Therefore, society hopes that harmony is always well maintained, and then they can avoid conflicts among them.

Society must establish social interactions in a cultural context properly in strengthening kinship relations of religious adherents. Society's effort in social interaction is to build a significant intensity of friendship. By good social interaction, relations between various religious adherents can work well so that conflicts can subside. Social interaction in a cultural context can be visiting the closest relatives because of a family event, a birth, thanksgiving, or others (Irawan 2018). Staying in touch with the closest relatives is reciprocal. If one family stays in touch with other families, the other families will stay in touch with the family. This friendship shows the society that is open to each other in building interactions in a cultural context. (Interview with Herlin Tungka, Bewa villager, South Lore District).

The conclusion is that the social and cultural interactions between community members can unite various religious adherents. The unification process occurs because each individual communicates socially and culturally, through which the community understands and respects each other's differences. After all, social and cultural interactions can make people know each other. Initially, the various religious adherents only know each other. Then they interact with each other and communicate so that the collective consciousness of the community to live in harmony grows well (Durkheim 2017). This collective consciousness based on socio-cultural interactions institutionalizes the idea of mutual respect and appreciation between religious communities. The fundamental point is that social and cultural interactions can build inter-religious harmony in South Lore and West Lore Districts.

\section{Cooperation}

Inter-religious cooperation is very fundamental to maintain interreligious harmony. By inter-religious cooperation in social fields, brotherhood and unity among religious adherents will exist in the infrastructure construc- 
tion and the implementation of religious holidays (Soleh 2011). The cooperation strengthens the collectivity of community relations and religious communities in carrying out joint activities to achieve a goal. This cooperation then builds consciousness to maintain inter-religious harmony (Irawan 2018).

The people in South Lore and West Lore districts, both Muslims and Christians, are very enthusiastic about community service because, through these activities, people can mingle and establish communication with each other. People call it morampu-rampu, cooperation in a particular program. This cooperation also extends to the socio-cultural space, strengthening community ties between government, community leaders, religious leaders, and society in general.

We still uphold the culture of communal work and cooperation because our ancestors taught us that living together (the Bada language Pohinae) will create harmony and a sense of family such as cooperation. If a member of our family dies, has a thanksgiving party, or has a wedding, we will come together to help him. It creates a sense of togetherness between us. When someone dies, the primary family must come to eat together to comfort the bereaved family. If it is a man who dies, his family must hold an event for nine days. If it is a woman who dies, her family must hold an event for ten days. This event always strengthens the brotherhood between us regardless of religion (Interview with Robinson Wengkau, the chief of sectoral police).

Cooperation in the cultural context is a concern between community members. This cooperation appears in an activity that benefits all parties with the principles of mutual trust, respect, and regulatory norms (Jamaludin 2016). It happens because human nature is a social creature. Humans cannot live alone and must live side by side with other humans. Humans always need help from others (Soekanto 2014). The community members cooperate with the people in the surrounding environment.

From the explanation, cooperation is a significant factor that maintains inter-religious harmony in South Lore and West Lore Districts. Actualization of cooperation occurs in the socio-cultural life of the community (Geertz 2000) through cooperation activities in completing a common goal. In this activity, the community will work together. In this cooperation, consciousness for mutual respect and respect between religious communities emerged. From 
here, cooperation has become an essential collective consciousness in maintaining inter-religious harmony in South Lore and West Lore Districts, Poso Regency.

\section{Consensus Decision-Making}

One way to encourage inter-religious harmony is consensus decisionmaking because, through consensus decision-making, the community can overcome problems with the principle of kinship (Ismail 2014). People in South Lore and West Lore districts used culturally to make consensus decisions as a daily activity in solving problems. They will consult when they hold parties, family events, sports activities, cooperation activities, a commemoration of religious holidays, and inter-religious dialogue. Consensus decisionmaking about these activities is always a priority. Deliberations unite interreligious relations.

In consensus decision-making, people always exchange opinions, ideas, and ideas. They resolve all differences in familial ways. The settlement creates public benefits such as a successful event and positive values (Ismail 2014). Through deliberation, communities can realize their common goals. Efforts in formulating this goal make people believe in the importance of unity and togetherness. Finally, they can ignore their differences.

The result of the consensus decision-making is something that everyone hopes for because it is a joint decision. In a social and religious activity, if the community wants to hold community service, it must make the consensus decision because through the consensus decision-making, the community to get a mutual agreement. In Bada, the community often holds the consensus decision-making at the village hall attended by community leaders. The most respected figures are a traditional leader and a religious figure called Mogombo (Interview with Alli Hussein, Imam of Almaidah Gintu Mosque)

Then, consensus decision-making became an essential activity in South Lore and West Lore Districts, Poso Regency. In carrying out community activities, consensus decision-making is a joint activity carried out in sociocultural life to avoid conflict (Jamaludin 2016). It shows that the community always wants to be harmonious.

People often make consensus decisions on inter-religious dialogue and religious holidays because consensus decision-making is essential to maintain inter-religious harmony. Without consensus decision-making, society is 
increasingly disorganized in holding religious activities. Therefore, community leaders and religious leaders are always active in dialogues and consensus decision-making, and conflicts in the Tampo Bada community decreases (Interview with Dumari, Pastor Klasis Tampo Bada Region). Consensus decision-making and dialogues between inter-religious adherents are the main factors for establishing harmony in a pluralistic society. Therefore, their expectations depend on such dialogue and consensus decision-making.

It confirms that consensus decision-making in inter-religious dialogue indicates that the community can live in peace. The community can interact well and promote the values of togetherness if they always make consensus decisions. Therefore, inter-religious adherents dialogue and make consensus decisions to build communication, coordination, order, and harmony in carrying out religious teachings. So, they can increase tolerance between inter-religious adherents to strengthen unity (Interview with Matthew Tungka, Civil Servant in the Office District Head of South Lore).

From the explanation, consensus decisions that the community makes routinely can maintain and improve religious harmony. Through consensus decision-making, every religious adherent has a dialogue to solve social issues and religion. By consensus decision-making, the community makes decisions that unite various religious adherents. Consensus decision-making is also a joint activity to solve community problems, and the community can realize a peaceful society even though different opinions often occur.

\section{Caring for Others and the Environment}

Community building is not just about interreligious interactions. It is also about building a sense of caring for others and the environment. Caring for others appears in helping each other regardless of differences and helping each other in every way, including the environment (Irawan 2018). The implementation of caring for others can be in the form of participating in community service or cooperation. Concern for the community and the environment also plays an essential role in maintaining inter-religious harmony in South Lore and West Lore Districts.

In maintaining harmony among others, a sense of brotherhood among each other must be a priority. The essence of brotherhood is an affection manifested in attention, care, solidarity, and empathy. (Interview with Simanang Cikka, Islamic Religious Leader). The implementation of brotherhood 
appears when various religious adherents carry out social activities or community service such as cleaning the surrounding environment, and then everyone participates and cooperates. All community takes active roles in social and environmental activities with pleasure regardless of religious diversities. It is the same in social activities. Even Christians are more disciplined than Muslims because they feel that they have the same responsibility in keeping the environment clean (Interview with Munna Hussein, Chairman of the Annisa Taklim Assembly).

From the explanation, all religious adherents always participate and take active roles in social and environmental activities. All of this depends on the spirit of dedication and concern for the environment and others. With social and environmental care activities, people can interact with each other. This activity is also a way to bring together various religious groups. Therefore, the community can realize inter-religious harmony; strengthen brotherly relations with various religious adherents (Interview with Dumari, one of the elders in the Presbyterian Church).

In addition, one form of care for others is cooperation in holding religious holidays and weddings. Through religious holidays and weddings, people help each other regardless of whether they are Muslim or Christian. The community mingled with each other at the time of the event. In these activities, the community can create and maintain inter-religious harmony. When there are celebrations for Eid al-Fitr and Christmas, they are always harmonious. Muslims and Christians always ask for help from community leaders and religious leaders regarding these activities. This support reflects the attitude of care for fellow religious adherents.

From the explanation, the response of some Muslims and Christians when commemorating religious holidays shows harmony and is a sign of close kinship. So when there are certain religious ceremonies such as Christmas, the local Muslim community will help and maintain security and comfort in carrying out worship on these holidays. From this, inter-religious harmony in the communities of South Lore and West Lore Districts exists because of an attitude of care for others and the environment.

\section{E. Conclusion}

In South Lore and West Lore Districts, harmony between religious adherents occurs because of good social-cultural interaction. This social- 
cultural interaction is in various social interactions such as cooperation, consensus decision-making, concern for others, and the environment. In the four social activities, the collective consciousness of the community develops well. This consciousness is consciousness regarding the importance of understanding, respecting, and appreciating religious diversities. This collective consciousness unites inter-religious relations to create harmony among religious communities in South Lore and West Lore Districts. The process of socio-cultural interaction as the communication medium for the people in South Lore and West Lore Districts is institutionalized in three spaces. The first is customs. Through customs, good social interaction occurs because the community still respects ancestral's values. The second is humanity. Good social interaction occurs because community respects humanitarian value. The third is the religion that regulates religious relations between communities that respect and appreciate religious activities carried out by the community. Through these three spaces, the socio-cultural interactions between community members in South Lore and West Lore Districts can eliminate the potential for religious conflict and maintain harmony among religious adherents.

\section{REFERENCES}

Durkheim, Emile. 2017. Sejarah Agama. Yogyakarta: Penerbit Ircisod.

Galib, M. 2014. Pluralitas Agama dalam Perspektif Al-Qur'an: Dari Toleransi Ke Kerjasama. Makassar: Alauddin Universitas Press.

Geertz, Clifford. 2000. Kebudayaan dan Agama. Yogyakarta: Penerbit Kanisius.

Hafidz, Abdurrahman. 2010. Diskursus Islam Politik dan Spiritual. Bogor: Al-Azhar Press.

Huberman, Mathew B. Milles dan A. Michel. 1992. Analisis Data Kualitatif. Jakarta: UI Press.

Irawan, Hanif. 2018. Proses Interaksi Sosial. Jakarta: Aksara Sinergi Media. Ismail, Faizal. 2014. Dinamika Kerukunan Antarumat Beragama: Konflik, Rekonsiliasi, dan Harmoni. Bandung: Remaja Rosdakarya.

Jamaludin, Adon Nasrullah. 2016. Agama dan Konflik Sosial. Bandung: Pustaka Setia. 
Moleong, Lexy J. 2016. Metodologi Penelitian Kualitatif. Bandung: PT Rosdakarya.

Nata, Abuddin. 2014. Metodologi Studi Islam Ed. Revisi. Jakarta: Rajawali Pers.

RI, Kementerian Agama. 2015. Al-Qur'an dan Terjemahnya. Bandung: Mizan. Shihab, M. Quraish. 2002. Tafsir Al-Mishbah: Pesan, Kesan, Dan Keserasian Al-Qur'an. Jakarta: Lentera Hati.

Soekanto, Sarjono. 2014. Sosiologi Suatu Pengantar. Jakarta: Rajawali press. Soleh, A. Khudori dan Erik. 2011. Kerja Sama Umat Beragama. Malang: UIN Malang Press.

SULTENG, Radar. 2017. "Kearifan-Lokal-Warga-Bada-Dalam MemeliharaPerdamaian-Dan-Cegah-Paham-Radikal.” Radarsultengonline.Com. 2017.

Surakhmad, Winarno. 1985. Pengantar Penelitian Ilmiah. Bandung: Tarsito. Wahyuni, Baharudin dan Esa Nur. 2015. Teori Belajar \& Pembelajaran. Yogyakarta: Ar-Ruzz Media.

Yunus, Abd. Rahim. 2012. Damai Dalam Islam: Perspektif Cita Dan Fakta. Makassar: Alauddin University Press. 